DOI https://doi.org/10.30525/978-9934-26-046-9-44

\title{
METHODS OF ENSURING THE ENVIRONMENTAL SAFETY OF AREAS WITH A TERRITORY NETWORK OF ROADS
}

\author{
Sheludchenko L. S. \\ Doctor of Technical Sciences, Associate Professor, \\ Associate Professor at the Department of Transport Technologies \\ State Agrarian and Engineering University in Podilya \\ Kamyanets-Podilsky, Khmelnytskyi region, Ukraine \\ Polishchuk D. V. \\ Candidate of Technical Sciences, \\ Associate Professor at the Department of Automobile Transport and \\ Transport Technology \\ Filial of Classic Private University \\ Kremenchuk, Poltava region, Ukraine \\ Nosko V. L. \\ Candidate of Technical Sciences, \\ Associate Professor at the Department of Machine Usage and \\ Technologies in Agriculture \\ Separated Subdivision of National University of Life and Environmental \\ Sciences of Ukraine «Berezhany Agrotechnical Institute» \\ Berezhany, Ternopil region, Ukraine
}

According to the results of complex theoretical and experimental researches, new scientific provisions, conclusions, and recommendations are proposed and substantiated in the scientific work. They will help to improve the level of ecological safety of natural-technogenic geoecosystem with a high density of the road network with heavy traffic flows by controlling the migration and deposition of gas-and-dust aerosols.

In general, we analyze the previous research and current trends in Ukraine and the world. It relates to the issue of environmental hazards in the area of influence of the road network. There have been established the main factors with the negative impact of roads on the ecological balance of natural-technogenic geoecosystem. They consist of alienated territories, dismemberment of natural landscapes, destabilization of natural-territorial 182 
complexes, pollution of roadside landscapes, which together lead to their irreversible transformation $[1,2,3]$.

On this basis, it has been determined that the migration of pollutants produced by motor traffic flows beyond the motorway lane. That is an important problem that has not been sufficiently resolved. It is proved that the dynamics of such uncontrolled migration is determined by the category of highway, which determines the intensity of vehicles, their transport and operating indicators, etc. In turn, the spread of pollutants depends on the characteristic features of natural landscapes and the presence of artificial objects for the protection of roadside areas. It has been determined that ecological rationalization of the landscape organization of the naturaltechnogenic geo-ecosystem is a priority decision regarding the possibility of managing the ecological safety of the territory with the developed road network.

It is established that the variability of the traffic conditions of the vehicles is functionally linked to the road network and landscape-territorial conditions of a specific natural-technogenic geo-ecosystem.

Subsequently they consist of changing the mode of movement of vehicles, the operation of internal combustion engines, fuel costs, and, as a consequence, to site-specific, functional characteristics of emissions of harmful substances, conditions of their subsequent migration and deposition [4].

On the basis of theoretical and experimental studies it is proved that the main factors of influence include structural features, technical level and operational condition of the highway. In addition, the transport capacity of the road, which is determined by the way the traffic is organized, provides both sufficient safety for each of its participants, and in turn, determines the level of technogenic and environmental safety of the motor transport complex as a whole.

Based on the findings, it is confirmed that the level of environmental safety of the area with a dense network of roads is complex. It requires the search for new and effective methods of constructing all vehicles without exception.

There was performed the substantiation of the theoretical and methodological base of the increase of ecological safety levels of naturaltechnogenic geo-ecosystems with high density of the road network and intensive flows of vehicles. They are based on the formed concept of scientific-applied problem and the basic working hypothesis. Thus, the functional characteristics of traffic flows were established according to the criteria of their continuity. Also, there has been made an analytical determination 
of the balance of volumes, structure and composition of pollutant emissions that are carried out under their influence.

Emissions of mineral dust and dust aerosols are determined in an analytical way. They depend on the processes of disintegration of mineral substances during the operation of roads and emissions as a result of abrasive wear of their construction. This component of the ecological safety of the transport infrastructure determines the structural features, technical level and operational condition of the highway.

Structure, gas emissions and soot are determined on the basis of a fraction of vehicles equipped with an internal combustion engine and a diesel engine. As a result of summarizing the material balance of the entire set of pollutant emissions, motorway categories have been established which exert a particularly dangerous influence on environmental objects by the volume of pollution of natural-techno-geo-ecosystems.

According to the results of studies of the dynamics of mass transfer and deposition of pollutants within the reserve technological roads, it is established that the surface roughness of the natural landscape and artificially created objects of the profile of the reserve technological road lane plays an important role. Furthermore, a special microclimate is created due to the anthropogenic changes in the landscape and the specific thermodynamic conditions of the atmosphere, which are caused by the influence of traffic flows. A stratification of the atmosphere is observed in the area of the highway. It should be used to control the airflows containing contaminants of transport emissions and their maximum deposition in the transverse profile of the highway. Structural support for the stratification of atmospheric layers adjacent to the roadway lane is realized through the use of gas-dust protective strips in the form of two-sided «geochemical» barriers. They should be fractal-consistent with natural landscapes with respect to their scientifically structural features and planting patterns of wood and shrubs. Also in the dissertation research there has been proposed the landscape-ecological optimization of the design of reserve-technological lanes of highways on sections with special traffic conditions (intersections, streamlines, etc.) [5].

In order to ensure the ecologically safe functioning of the motor transport complex, an indicator of the transport capacity of the territorial communication structure was used. In terms of system analysis it is considered to be one of the defining features of this structure. It is an integral part of the transport and communication transit «corridors» of energy and substance metabolism in the system and forms an appropriate demographic and economic framework. Thus, ecological and technological optimization 
of the support frame of the road network of the natural-technogenic geoecosystem was carried out. It ensures ecological balance (ecological security) of the natural-territorial complex. As an example of this optimization of the support frame of the road network, the paper presents graph-analytical optimization of the motor transport infrastructure of the Podolsk region within the Khmelnytsky district.

In general, it has been established that the landscape organization of the NATESA (natural-technogenic safety of hydro-ecosystems) with the developed road network should be considered as a mosaic complex. It consists of separate landscape-territorial basins with the unity of common landscape features. Each of them should be topologically characterized by the principal axes and their geometric center. And they should be limited by some dominants of the basin fragment of the NATESA. Thus, the increase of the capacity of the NATESA motor vehicle should be done by creating artificial landscape objects. In turn, they will enhance the geomorphological features of the highway landscape and territorial basin [6].

On the basis of theoretical and experimental researches there have been developed the procedure and algorithm of project management of NATESA with the developed motor transport network for application in automated design systems. There also have been substantiated the corresponding recommendations for the project organizations and institutions.

\section{References:}

1. Екологічна безпека та економіка : монографія / M.I. Сокур, B.М. Шмандій, Є.К. Бабець, В.С. Білецький, І.С. Мельнікова, О.В. Харламова, Л.С. Шелудченко. - Кременчук, ПП Щербатих О.В., 2020. - $240 \mathrm{c}$.

2. Внукова Н.В. Оцінювання інтегрального техногенного навантаження при функціонуванні автотранспортних систем. Захист навколишнього середовища. Енергоощадність. Збалансоване природокористування: збірник матеріалів 5-го Міжнародного конгресу. - Львів, Видавництво Львівської політехніки, 2018. - С. 40.

3. Харламова О.В., Шмандій В.М.,Поліщук Д.В., Котенко О.Л., Гученко М.І. Моніторинг станів екологічної небезпеки при сумісній дії стаціонарних та пересувних джерел. Науковий журнал «Екологічна безпека». Кременчук: КрНУ, 2017 № 2/2017 (24). С. 27-31.

4. Sheludchenko L., Ivanyshyn V., Hutsol T., Rud A., Skorobogatov D. Mass transfer management and deposition of contaminants within car road zones. Environment. Technology. Resources. Proceedings of the 12th 
International Scientific and Practical Conference / Volume 1. Rezekne Academy of Technologies, (2019). P. 70-74.

5. Sheludchenko L. Dynamics modeling of traffic-related exhaust aerosol. Scientific journal «Environmental problems» Vol. 2, №4. - Lviv: Lviv Polytechnic Publishing House, 2017. P. 191-194.

6. Providing environmental safety in the conditions of the dense road network: Modern engineering research: topical problems, challenges and modernity: Collective monograph / Sheludchenko L., Semenyshena R. Riga : Izdevnieciba «Bultija Publishing», 2020. P. 498-516. 